\title{
Development of Ionic Liquid-based Magnetic Nanoparticle-supported Dispersive Liquid Liquid Microextraction Technique for Mercury Preconcentration Prior to Hydride Generation Atomic Absorption Spectrometry in Aqueous Samples
}

\author{
Mine Antep \\ Dokuz Eylul University, Faculty of Science, Chemistry Department, \\ Kaynaklar Campus, 35160 Izmir, Turkey
}

\begin{abstract}
A simple and efficient ionic liquid-based magnetic nanoparticle-supported dispersive liquid liquid microextraction (ILMDLLME) method was developed to enrich mercury before its determination by flow injectionhydride generation atomic absorption spectrometry. In this experiment, imidazolium hexaflurophosphate ionic liquid, having different cationic groups as 1-allyl/butyl/methyl, was used to extract mercury-4-(2-pyridylazo) resorsinol complex from aqueous samples into fine droplets. After adding of $\mathrm{Fe}_{3} \mathrm{O}_{4}$ MNPs to the extraction media, enriched mercury was separated from the aqueous solution using an external magnet. Some analytical parameters influencing the efficiency of the proposed (IL-mDMME) method, such as $\mathrm{pH}$, amount of
\end{abstract}

IL, ligand concentration, extraction time, amount of $\mathrm{Fe}_{3} \mathrm{O}_{4}$ MNPs, sample volume and matrix effect, were optimized.

Under the optimized conditions, good linearity was obtained with correlation coefficients (r) greater than 0.9938 . The repeatability and reproducibility of the proposed method were found to be good, and the limits of detection ranged from $0.18 \mu \mathrm{g} \mathrm{L}^{-1}$ to $0.54 \mu \mathrm{g} \mathrm{L}^{-1}$ for the studied ionic liquids. The accuracy of the proposed method, was assessed by standard addition method calculated by relative standard deviations in the range of $100-110 \%$ for tap water and $97-$ $100 \%$ for mineral water. Within this extraction technique, fast, green, and efficient enrichment of mercury was achieved by centrifugation steps using environmentally friendly ionic lquids and obtaining high enrichment factors.

\section{INTRODUCTION}

In recent years, new approaches to analytical chemistry have focused on the miniaturization and simplifiication of the sample preparation steps. Dispersive liquid liquid microextraction (DLLME) has become the most preferred technique due to the large surface area of the extractant and high extraction recovery within a short time (1-5). Ionic liquids have been used

Corresponding autbor.

E-mail: mine.kurtbay@deu.edu.tr

Tel: +902323017909

Fax: +90 2324534188 as a green extractant in DLLME since $2008(4,6)$ because of their efficient chemistry, using low toxic media, vapor pressure, and having adjustable viscosity, etc. (7-11). Zhang et al. (12) used 1-hexyl-3methylimidazolium hexafluorophosphate for the preconcentration of triazole herbicides, and Tuzen and Pekiner (13) used 1-hexyl-3methylimidazolium bis (trifluoromethylsulfonyl) imide for speciacition of selenium. In some cases, ionic liquids (ILs) have caused some disadvantages when used with dispersive solvents such as methanol, acetone, acetonitrile, decanol, 2-propanol, etc. There- fore, new strategies have been adopted to DLLME by using portable, economical, and effective external magnetic nanoparticles (MNP) (14) for easy separation of trace amounts of metal ions such as $\mathrm{Cr}, \mathrm{Cu}$, and $\mathrm{Pb}$ or herbicides, uric acid, etc., from aqueous samples $(15,16)$ and to reach equilibrium in a short time. This results in mass transfer of the analytes from the aqueous phase to the organic phase $(17,18)$.

In this study, mercury (Hg), one of the most toxic heavy metals, was preconcentrated using ionic liquidbased magnetic nanoparticle-supported DLLME prior to its determination by flow injection-cold vapor atomic absorption spectrometry (FI-CVAAS). Mercury can cause dangerous cumulative effects to the central nervous system, respiratory failure, hypertension, chromosomal disorders, cerebral palsy, even death (19). In addition, chronic exposure to $\mathrm{Hg}$ (II) causes renal damage and morphological changes, renal tubular damage, regeneration of the tubular epithelium, and proximal tubular necrosis (20). The tolerable limit of inorganic mercury in drinking water is $6 \mu \mathrm{g} \mathrm{L}^{-1}$ (21).

Because of its high toxicity and the bioaccumulation factor, mercury determination is very important in environmental and biological samples such as soil, sediment, wastewater, and groundwater (22-24).

In this study, three imidazoliumbased ionic liquids of different cationic groups (allyl, butyl, and methyl) were studied and compared. 
Within the developed technique, the enriched mercury phase was collected onto the magnetic Fe(III) oxide $\left(\mathrm{Fe}_{3} \mathrm{O}_{4}\right)$ nanoparticles, separated with an external magnet, and directly analyzed. Thus, in the centrifugation step no extraction process was applied, the analysis was performed, and application of the MNPs in the ionic liquid-based DLLME was found to be a rapid, effective, and green microextraction technique.

\section{EXPERIMENTAL}

\section{Instrumentation}

For synthesis of AMIM-PF 6 , a Buchi rotary evaporator (Flawil, Switzerland), Selecta $2001 \mathrm{pH}$ meter (Barcelona, Spain), ultrasonic bath (Nuve, Turkey), and Labconco FreezeZone Freeze-Dryer 2.5 (Labconco Corporation, USA) were used.

Spectrum BX-II FTIR (PerkinElmer, Inc., USA), Philips X'Pert Pro XRD (X'Celerator detector), FEI Tecnai $G^{2}$ Spirit Biotwin TEM, Shimadzu UV-1800 spectro- photometer (Kyoto, Japan), and Varian Cary Eclipse spectrofluorometer (Palo Alto, CA, USA) were used for the characterization studies of the synthesized ionic liquid and the prepared $\mathrm{Fe}_{3} \mathrm{O}_{4}$ magnetic nanoparticles.

Quantitative analysis of mercury was performed using the AAnalyst ${ }^{\mathrm{TM}}$ 700 , equipped with a FIAS ${ }^{\text {TM }} 100$ hydride generation system (PerkinElmer, Inc., USA). A Hg-EDL lamp was used. The instrumental parameters are summarized in Table I.

\section{Chemicals, Reagents, and Standard Solutions}

Analytical grade ionic liquids 1-allyl-3-methylimidazolium chloride (AMIM-Cl), 1-butyl-3-methylimidazolium hexafluorophosphate (BMIM-PF 6 ), 1-benzyl-3-methylimidazolium hexafluorophosphate (BeMIM-PF ${ }_{6}$, and ammonium hexa- fluorophosphate $\left(\mathrm{NH}_{4}-\mathrm{PF}_{6}\right)$ were purchased from Sigma-Aldrich (St. Louis, MO, USA) and Alfa Aesar (Haverhill, MA, USA).

Dichloromethane, ethanol $\left(\mathrm{C}_{2} \mathrm{H}_{5} \mathrm{OH}\right)$, hydrochloric acid $(\mathrm{HCl})$, nitric acid $\left(\mathrm{HNO}_{3}\right)$, acetic acid, $\mathrm{pH}$ buffer solutions and $\mathrm{Fe}(\mathrm{II}) / \mathrm{Fe}$ (III) chloride, sodium borohydride, potassium permanganate $\left(\mathrm{KMnO}_{4}\right)$, sodium acetate, sodium hydroxide $(\mathrm{NaOH})$, Triton ${ }^{\circledR} \mathrm{X}-100$, sodium dodesyl sulfate, hexadecylcetyltrimethyl ammonium bromide were purchased from E. Merck, SigmaAldrich or Alfa Aesar. Deionized water was obtained with a Milli-Q ${ }^{\circledR}$ water purification system (Millipore Corporation, USA).

The individual stock standard solution of mercury (1000 mg/L) was purchased from PerkinElmer, Inc. (Shelton, CT, USA). The working solutions were prepared daily by dilution of the stock standard solution of mercury. All working and stock solutions were stored in a refrigerator at $+4^{\circ} \mathrm{C}$.

1-allyl-3-methylimidazolium hexafluorophosphate was prepared as reported in the literature (25). Briefly, 0.02 moles of AMIM-Cl and $50 \mathrm{~mL}$ of dichlorometane were mixed in a flat bottom flask. Then, 0.02 moles of $\mathrm{NH}_{4}-\mathrm{PF}_{6}$ was added and reacted by stirring for 24 hours at room temperature. Later, the pre-

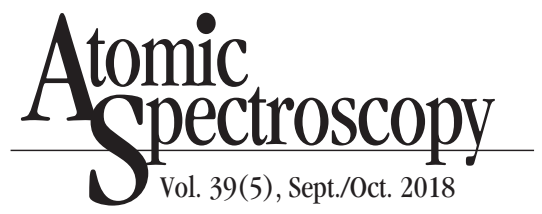

cipitated ammonium bromide was filtered and discharged. The organic phase was evaporated and 1-allyl-3methylimidazolium hexafluorophosphate (AMIM-PF 6 ) was obtained.

For characterization of AMIM$\mathrm{PF}_{6}$, the FTIR and 1H-NMR spectra were recorded and the resuls are given as follows:

FTIR $\left(\mathrm{cm}^{-1}\right)$ : 3100-3050 (aromatic $=\mathrm{C}-\mathrm{H}$ stretching), 2950-2850 (aliphatic simetric and asymetric -C-H stretching), 1570-1560 (C=N stretching), 1460-1450 (C=C stretching vibrations, 1330-1280 and 1168-1050 (-C-H streching and -C-C stretching), 847-719 (aromatic $=$ C-H out-of-plane bending).

1H-NMR (CDCl3): 8.39 ppm (s, 1H, NCHN), 7.03 ppm (d, 2H, $\mathrm{NCH}_{2} \mathrm{CHCH}_{2}$ ), $5.6 \mathrm{ppm}(\mathrm{m}, 5 \mathrm{H}$, $\left.\mathrm{NCH}_{2} \mathrm{CHCH}_{2}\right), 5.0 \mathrm{ppm}(\mathrm{m}, 2 \mathrm{xCH}$, NCHCHN), $4.42 \mathrm{ppm}$ (d, 2H, $\mathrm{NCH}_{2} \mathrm{CHCH}_{2}$ ), $3.52 \mathrm{ppm}(\mathrm{s}, 1 \mathrm{H}$, $\mathrm{NCH}_{3}$ ).

\section{Preparation of $\mathrm{Fe}_{3} \mathrm{O}_{4}$ Magnetic Nanoparticles}

For the preparation of $\mathrm{Fe}_{3} \mathrm{O}_{4}$ MNP, $11.6 \mathrm{~g}$ of $\mathrm{FeCl}_{3} \cdot 6 \mathrm{H}_{2} \mathrm{O}$ was dissolved with $200 \mathrm{~mL}$ ultrapure water for 5 minutes in an ultrasonic bath. Then, $4.3 \mathrm{~g}$ of $\mathrm{FeCl}_{2} \cdot 4 \mathrm{H}_{2} \mathrm{O}$ was added and stirred at $80^{\circ} \mathrm{C}$ for 15 minutes under a $\mathrm{N}_{2}$ stream, ultra-

TABLE I

Instrumental Operating Conditions

\begin{tabular}{ll}
\hline AAnalyst 700 FAAS & \\
\hline Wavelength & $253.7 \mathrm{~nm}$ \\
Slit dimension & $0.7 \mathrm{~nm}$ \\
EDL current & $185 \mathrm{~mA}$ \\
Flow rate of argon & $100-110 \mathrm{~mL} / \mathrm{min}$ \\
\hline FIAS 100 & \\
\hline Carrier & $\mathrm{HCl}(3 \%, \mathrm{v} / \mathrm{v})$ \\
Reductant & $\mathrm{NaBH}_{4}(0.2 \%, \mathrm{w} / \mathrm{v})$ in $0.05 \%(\mathrm{w} / \mathrm{v}) \mathrm{NaOH}$ \\
Stabilization & $\mathrm{KMnO}_{4}(5 \%, \mathrm{w} / \mathrm{v})$ \\
Cell temperature & $100{ }^{\circ} \mathrm{C}$ \\
\hline
\end{tabular}


sonically. Then, $40 \mathrm{~mL}$ of $\mathrm{NH}_{3}$ (25\%, v/v) was added with a funnel. After the ammonia addition, a black solid precipitate was formed (magnetic nanoparticle suspension), stirred for 15 minutes ultrasonically, and separated by the application of an external magnet, then washed with water, and finally dried with a freeze dryer (26).

The characteristic infrared bands of $\mathrm{Fe}_{3} \mathrm{O}_{4} \mathrm{MNP}$ are shown in Figure 1a. The Fe-O-Fe streching vibration was observed at $600-550 \mathrm{~cm}^{-1}$ (27) and the $\mathrm{Fe}-\mathrm{O}-\mathrm{Fe}$ characteristic vibration at $588 \mathrm{~cm}^{-1}$. Also, the peak at $1629 \mathrm{~cm}^{-1}$ is assigned to the O-H bending (28). For XRD characterization of $\mathrm{Fe}_{3} \mathrm{O}_{4} \mathrm{MNP}$, all characteristics at $20^{\circ}$ were recorded in Figure 1b. The characteristics at $20^{\circ}$ are seen at 30.3, 35.7, 43.1, 53.8, 57.1, 62.7 corresponding to (220), (311), (400), (422), (511), (440) peaks, respectively (29).

\section{Ionic Liquid-based Magnetic DLLME Method}

Five milliliters of aqueous solution containing $40 \mu \mathrm{g} \mathrm{L}^{-1}$ of $\mathrm{Hg}$ (II), $10 \times 10^{-6} \mathrm{~mol} \mathrm{~L}^{-1}$ of PAR, $2 \mathrm{~mL}$ of $\mathrm{pH}$ 7 buffer and $4 \%(\mathrm{v} / \mathrm{v})$ of the BMIM$\mathrm{PF}_{6}$ were placed in a test tube and completed to $10 \mathrm{~mL}$ with ultrapure water. Then $50 \mathrm{mg}$ of $\mathrm{Fe}_{3} \mathrm{O}_{4}$ was added to the tube. The mixture was ultrasonically shaken for 120 sec- onds. A magnet was subsequently held around the test tube to collect the nanoparticles at the bottom of the test tube. The upper aqueous phase was removed and $500 \mu \mathrm{L}$ of $3 \%(\mathrm{w} / \mathrm{v}) \mathrm{HCl}$ was added to the enriched phase. Then, the solution was vortexed for 30 seconds to desorb the IL as well as the $\mathrm{Hg}$ (II) from the MNPs.

Finally, the nanoparticles were isolated from the solution with a magnet, and the rich phase was diluted to $5 \mathrm{~mL}$ with $3 \%$ (w/v) $\mathrm{HCl}$ before spectroscopic analysis.

\section{Samples}

Optimized extraction conditions were applied to tap water and mineral water samples. The water sample was collected directly at the laboratory and allowed to stand for 30 minutes, while the mineral water sample was degassed ultrasonically for 15 minutes. All samples were filtered through $0.45 \mu \mathrm{m}$ pore-sized disc filters prior to extraction and analysis.

\section{RESULTS AND DISCUSSION}

\section{Optimization of Extraction Parameters}

The optimization parameters were studied for $\mathrm{pH}$, surfactant, ionic liquid, magnetic nanoparticle, and extraction time. Determination of the optimum extraction value of all steps, percentage of extraction recovery (E \%) was calculated using the following equation:

$$
E(\%)=\frac{C_{\text {sed }}}{C_{0}} \times \frac{V_{\text {sed }}}{V_{0}} \times 100
$$

where,

$\mathrm{C}_{\text {sed }}=$ concentration of the analyte in the sedimented phase, $\mathrm{C}_{0}=$ initial concentration of the analyte in the aqueous sample, $V_{\text {sed }}=$ volume of the sedimented phase, and $\mathrm{V}_{0}=$ volume of the aqueous phase.

\section{pH of Complexation}

The ligand of PAR (4-(2-Pyridylazo)resorcinol) forms strong complexes with metal ions through the heterocyclic nitrogen group, azo group, and o-hydroxyl group in its structure. The PAR molecule is a dibasic acid and the complex formation is directly dependent on the $\mathrm{pH}$ of the solution medium. For this reason, the $\mathrm{pH}$ of the extraction media was determined at first using buffer solutions with $\mathrm{pH}$ values ranging from $3,4,5,5.5,6,7,8$, to 9. The obtained results in Figure 2 show that highest extraction recovery was obtained around $\mathrm{pH} 6$.

\section{Effect of Surfactant}

Surfactant selection is a factor that affects the efficiency of pre-

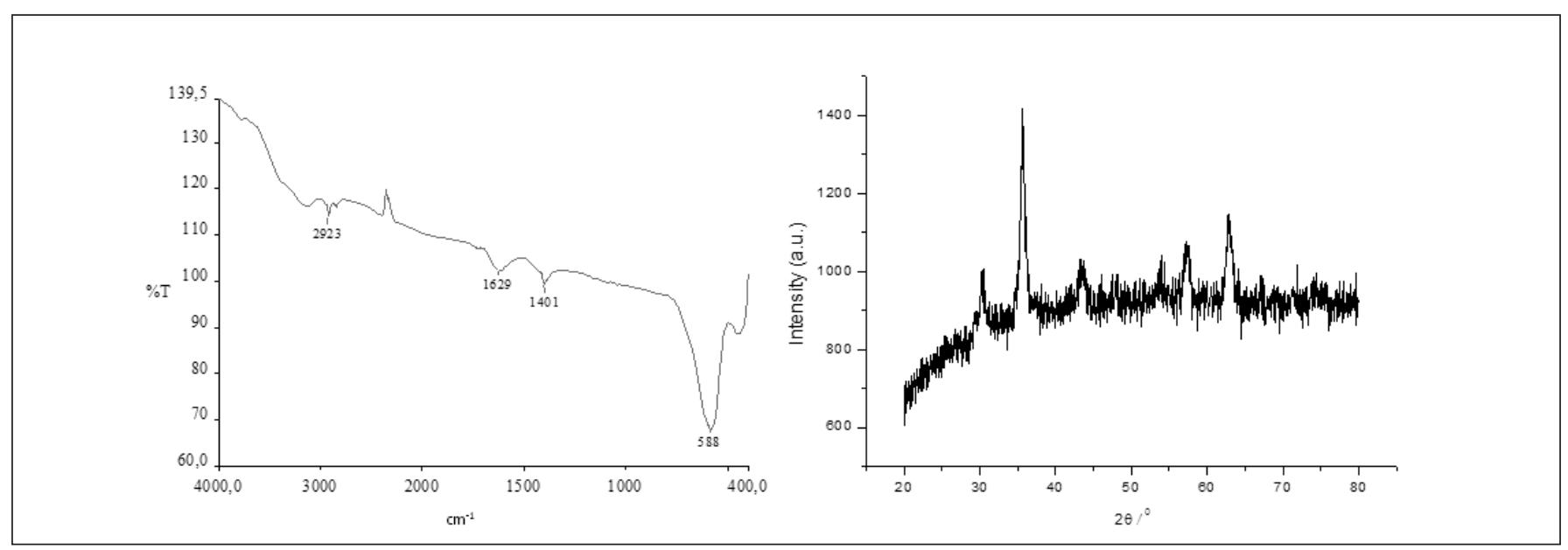

Fig. 1. Characterization of $\mathrm{Fe}_{3} \mathrm{O}_{4} \mathrm{MNP}$ : (a) FTIR spectrum, (b) XRD spectrum. 
concentration in the extraction and is effective in dissolving the waterimmiscible extraction solvent in the aqueous sample. Experiments were conducted with aqueous solutions of sodium dodecyl sulfate (SDS), Triton ${ }^{\circledR}$ X-100 (TX-100), and cetyl trimethylammonium bromide (CTAB) at $1 \times 10^{-5} \mathrm{M}$ concentrations to investigate the surfactant effect on mercury preconcentration. As shown in Figure 3, addition of the surfactant did not have an effect on the recovery of mercury for BMIM$\mathrm{PF}_{6}$ and $\mathrm{BeMIM}-\mathrm{PF}_{6}$, while the addition of CTAB caused an increase on the extraction recovery for AMIM$\mathrm{PF}_{6}$.

Therefore, the effect of CTAB amount was studied as the next optimization step only for AMIM$\mathrm{PF}_{6}$. For this, CTAB was added at different concentrations from $2 \times 10^{-6} \mathrm{M}$ to $1.5 \times 10^{-5} \mathrm{M}$ for four levels into the aqueous solution. As seen in Figure 3, the exraction yield increased up at $5 \times 10^{-6} \mathrm{M}$ and became maximum at $1 \times 10^{-5} \mathrm{M}$, For subsequent studies, AMIM-PF 6 was performed with $1 \times 10^{-5} \mathrm{M}$ of CTAB.

\section{Effect of Amount of PAR}

In the IL-based extraction method applied in this study, it is necessary to form the hydrophobic complex of the analyte before adding the ionic liquid to the extraction medium. For this, the type and amount of chelating agent are the key factor. PAR is a widely used ligand for many applications, such as metal extraction, spectrophotometric and chromatographic metal ion analysis, forming many metal-colored complexes. In the structure, a strong heterocyclic nitrogen group, metal groups containing an azo group and o- is a ligand that forms complexes (30-32).

In order to get high extraction yield, the required amount of PAR was investigated from $0.5 \times 10^{-6} \mathrm{M}$ to $20 \times 10^{-6} \mathrm{M}$. With a PAR from 0.5 to $2 \times 10^{-6} \mathrm{M}$, the extraction recovery increased from $20 \%$ to $60 \%$ for AMIM-PF 6 . For BMIM-PF 6 , the effect of PAR amount affected the recovery by dynamically increasing to $1 \times 10^{-5} \mathrm{M}$. After that amount, extraction recovery was almost stable.
While adding $0.5 \times 10^{-6} \mathrm{M}$ of PAR to BeMIM-PF ${ }_{6}$ media, the extraction recovery was optimal at $60 \%$, though adding the higher amount of PAR decreased the extraction recovery. Following, the extraction recoveries obtained were evaluated for all three ionic liquids. The highest extraction was obtained at concentrations of $2 \times 10^{-6} \mathrm{M}$ PAR for AMIM-PF $_{6}, 1 \times 10^{-5}$ M PAR for BMIM$\mathrm{PF}_{6}$, and $0.5 \times 10^{-6} \mathrm{M}$ PAR for BeMIM$\mathrm{PF}_{6}$ (Figure 4).

\section{Effect of Amount of Ionic Liquid}

To optimize the amount of ionic liquid, the experiments were carried out for varying amounts of AMIM-PF $_{6}$, BMIM-PF $_{6}$ and BeMIM$\mathrm{PF}_{6}$ ionic liquids. For this, different concentrations of the ionic liquids used from $2 \%$ to $10 \%$ (v/v for $\mathrm{AMIM}^{-\mathrm{PF}_{6}}$ and $\mathrm{BMIMPF}_{6}, \mathrm{w} / \mathrm{v}$ for

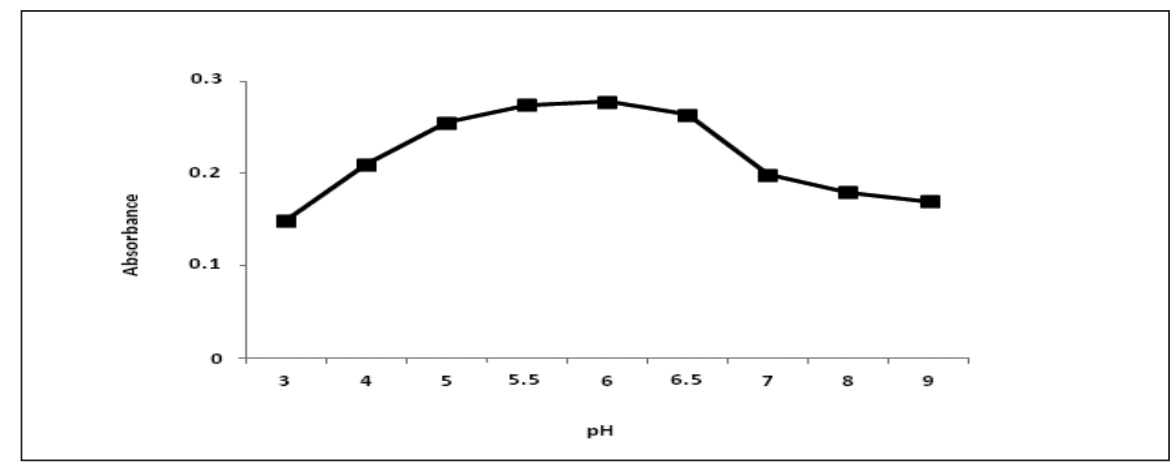

Fig. 2. Effect of pH. Conditions: $10 \mathrm{~mL}$ of working solution; $40 \mu \mathrm{g} / \mathrm{L}$ of $\mathrm{Hg}(\mathrm{II})$; $1 \times 10^{-5} \mathrm{MPAR} ; 25 \mathrm{mg}$ of $\mathrm{Fe}_{3} \mathrm{O}_{4} ; 5$ min extraction time.

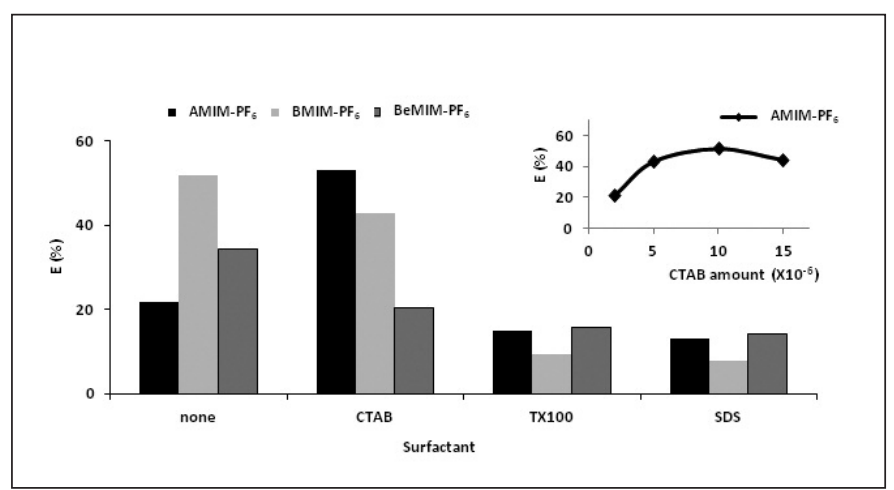

Fig. 3. Effect of surfactant. Conditions: $10 \mathrm{~mL}$ of working solution; $40 \mathrm{\mu g} / \mathrm{L}$ of $\mathrm{Hg}(\mathrm{II}) ; \mathrm{pH} 6 ; 1 \times 10^{-5} \mathrm{M} \mathrm{PAR} ; 25 \mathrm{mg}$ of $\mathrm{Fe}_{3} \mathrm{O}_{4}$; 5 min. extraction time.

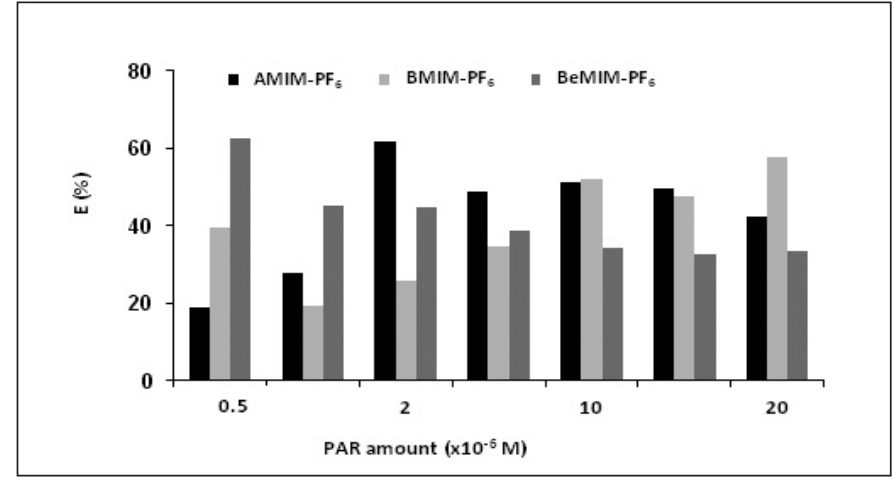

Fig. 4. Effect of PAR. Conditions: $10 \mathrm{~mL}$ of working solution; $40 \mu \mathrm{g} / \mathrm{L}$ of $\mathrm{Hg}(\mathrm{II}) ; \mathrm{pH}$ 6; $25 \mathrm{mg}$ of $\mathrm{Fe}_{3} \mathrm{O}_{4} ; 5$ min. extraction time. 
BeMIM-PF 6 ) were added to the aqueous solution containing $40 \mu \mathrm{g} \mathrm{L}^{-1}$ of mercury. The optimized amount for each ionic liquid was determined as $6 \%, 4 \%$, and $3 \%$ for AMIM-PF 6 , BMIM-PF, BeMIM-PF, respectively (Figure 5).

\section{Effect of $\mathrm{Fe}_{3} \mathrm{O}_{4} \mathrm{MNP}$}

Compared to conventional micron-sized adsorbents, MNPs offer high extraction capacity, fast extraction dynamics, and high extraction efficiency. Satisfactory results can therefore be obtained with lower amounts of these adsorbents. For this, the effect of MNP on the enrichment of mercury by IL-mDLLME was examined with different amounts of $\mathrm{Fe}_{3} \mathrm{O}_{4}$ with MNPs ranging from 10 to $100 \mathrm{mg}$. As seen in Figure 6, while the MNP amount increased to $25 \mathrm{mg}$ for $\mathrm{AMIM}^{-\mathrm{PF}_{6}}$

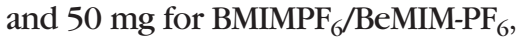
the extraction recoveries were increasing from $25 \%$ to 60,70 , nearly $100 \%$ for each ionic liquid, respectively. After these amounts, the extraction recoveries decreased. Thus, the optimized amount for highest extraction recoveries was found to be $\mathrm{Fe}_{3} \mathrm{O}_{4} \mathrm{MNP}$ as $25 \mathrm{mg}$ for $\mathrm{AMIM}-\mathrm{PF}_{6}$ and $50 \mathrm{mg}$ for BMIM$\mathrm{PF}_{6}$ and $\mathrm{BMIM}-\mathrm{PF}_{6}$.

\section{Effect of Desorption Solution}

In this IL-mDLLME extraction process, desorption of enriched mercury from loaded $\mathrm{Fe}_{3} \mathrm{O}_{4} \mathrm{MNP}$ including IL is an important step. For this, different acidic and/or alcoholic solutions and their mixtures like ethanol, $\mathrm{HCl}(3 \%, \mathrm{v} / \mathrm{v})$, $\mathrm{HNO}_{3}\left(65 \%\right.$, w/v), $\mathrm{C}_{2} \mathrm{H}_{5} \mathrm{OH}: \mathrm{HNO}_{3}$ (1:1, v/v), $\mathrm{C}_{2} \mathrm{H}_{5} \mathrm{OH}: \mathrm{HCl}(1: 1, \mathrm{v} / \mathrm{v})$ were studied. From the results obtained, the best desorption was achieved using $\mathrm{C}_{2} \mathrm{H}_{5} \mathrm{OH}: \mathrm{HNO}_{3}$ (1:1, $\mathrm{v} / \mathrm{v})$ for $\mathrm{AMIM}-\mathrm{PF}_{6}, 3 \% \mathrm{HCl}(\mathrm{w} / \mathrm{v})$ for

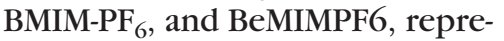
senting $69.3 \%$ and $100.0 \%$.

\section{Effect of Extraction Time}

Extraction time is one of the most important factors of the ILmDLLME method. Extraction time is defined as the time from the injection of the dispersive and the extraction solvent mixture to centrifugation. It is also known to be an effective way to improve mass transfer from the aqueous phase to the extraction phase in the case of inclusion of the vortex mixing process. In this study, the effect of extraction time was controlled between 30 and 300 seconds. As shown in Figure 7 , highest recovery was found in the range of 60 to 180 seconds. As can be seen from the graph, the optimized extraction recovery was reached at 60 seconds for $\mathrm{AMIM}-\mathrm{PF}_{6}$ and BMIM-PF, 180 seconds for BeMIM-PF 6 .

\section{Interference Studies}

In the present study, PAR was selected as complexing agent for mercury in aqueous samples. It can also react with other metal ions to form their complexes that may cause the interferences on mercury. Thus, some metal ions $\left(\mathrm{Al}^{3+}, \mathrm{Cu}^{2+}\right.$, $\mathrm{Fe}^{3+}, \mathrm{Mn}^{2+}, \mathrm{Ni}^{2+}, \mathrm{Pb}^{2+}, \mathrm{Zn}^{2}$, etc. $)$

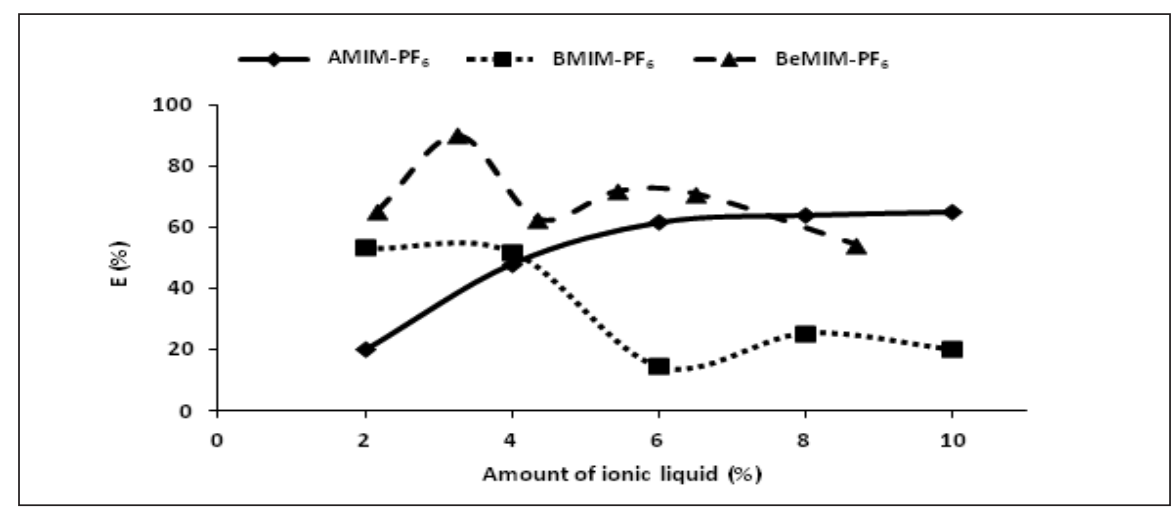

Fig. 5. Effect of ionic liquid. Conditions: $10 \mathrm{~mL}$ of working solution; $40 \mu \mathrm{g} / \mathrm{L}$ of $\mathrm{Hg}(\mathrm{II}) ; \mathrm{pH}$ 6; $25 \mathrm{mg}$ of $\mathrm{Fe}_{3} \mathrm{O}_{4} ; 5$ min. extraction time.

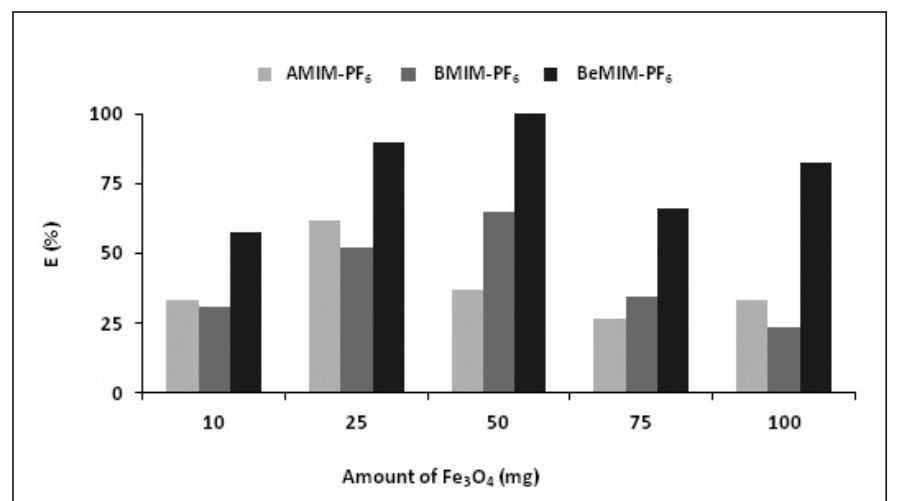

Fig. 6. Effect of $\mathrm{Fe}_{3} \mathrm{O}_{4}$. Conditions: $10 \mathrm{~mL}$ of working solution; $40 \mu g / L$ of $H g(I I) ; p H ~ 6 ; 5$ min. extraction time.

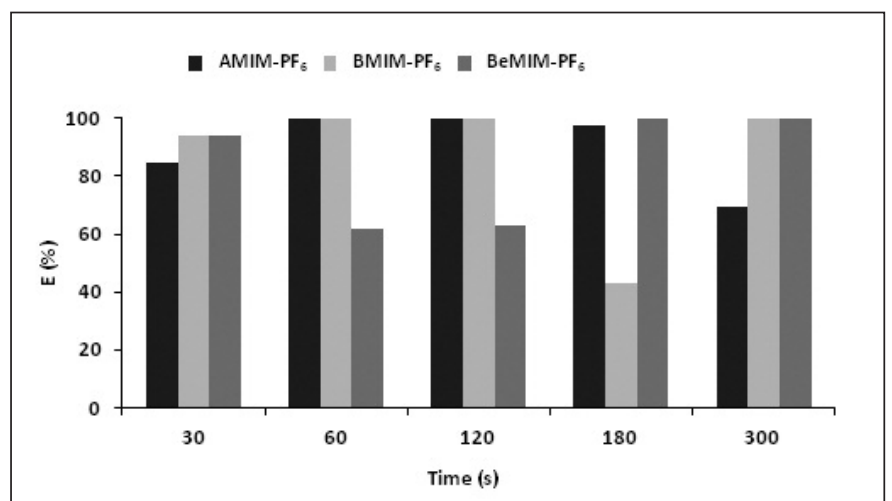

Fig. 7. Effect of extraction time. Conditions: $10 \mathrm{~mL}$ of working solution; $40 \mu g / L$ of $\mathrm{Hg}(\mathrm{II}) ; \mathrm{pH} 6$. 
commonly determined in water samples were studied on the extraction. Beside this, the complexation behavior of the ionic species by anionic forms $\left(\mathrm{Cl}^{-}, \mathrm{NO}_{3}{ }^{-}\right.$, etc.) may influence the efficiency of the extraction. Under optimized conditions according to the proposed method, the effect of some foreign ions such as $\mathrm{Pb}$ (II), Mn(II), $\mathrm{Ni}(\mathrm{II})$, and $\mathrm{Fe}$ (III) in the determination of $\mathrm{Hg}$ (II) at $40 \mu \mathrm{g} \mathrm{L}^{-1}$ was investigated. The interfering ions and the recovery values are given in Table II.

Most of the cations and anions are tolerated up to high levels (up to $25 \mu \mathrm{g} \mathrm{L}^{-1}$ ). A species resulting in more than $10 \%$ variation in the recovery of the target analyte is considered as an interfering agent $90-95 \%$. This could be reduced by adding some suitable masking agents to the extraction medium.

\section{Analytical Figures of Merit of the IL-mDLLME Method}

The calibration data of mercury were obtained using an HG-AAS system after the preconcentration step. Besides this, the linear range and correlation coefficient $\left(\mathrm{R}^{2}\right)$ were determined. Also, the limit of detection (LOD) was calculated by 10 blank measurements as $3 x S$. The precision of the method was determined for intra- and inter-day as relative standard deviation (\%RSD). Applicability of the method was evaluated by analyzing tap water and mineral water samples using the developed method. Accuracy studies were accomplished by calculating the relative standard deviation from the added or known amount of mercury to the water samples and investigated by the recovery experiments of the samples. For the optimum extraction conditions, the enrichment factor (EF) was calculated for AMIM-PF $\mathrm{BMIM}^{-\mathrm{PF}_{6}}$, and $\mathrm{BeMIM}-\mathrm{PF}_{6}$ ionic liquids depending on the ratio of the concentration of $\mathrm{Hg}$ (II) in the enriched phase to the initial concentration of $\mathrm{Hg}$ (II) in the aqueous sample. All analyitcal parameters for each ionic liquid-based mDLLME method are given in Table III.

Sample volume for an analysis is an important factor due to the low concentration of mercury in water samples. To survey the effect of sample volume on the recovery, different volumes of sample solutions $(5,10,20,30,40$, and $50 \mathrm{~mL})$

TABLE II

Interference Effect

\begin{tabular}{lcc|ccc}
\hline Ion & $\begin{array}{r}\text { Conc. } \\
\left(\mu \mathrm{g} \mathrm{L}^{-1}\right)\end{array}$ & $\begin{array}{c}\text { Extractn. } \\
\text { \%Recov. }\end{array}$ & Ion & $\begin{array}{r}\text { Conc. } \\
\left(\mu \mathrm{g} \mathrm{L}^{-1}\right)\end{array}$ & $\begin{array}{r}\text { Extractn. } \\
\% \text { Recov. }\end{array}$ \\
\hline $\mathrm{Pb}^{2+}$ & 5 & 94 & $\mathrm{Fe}^{2+}$ & 10 & 90 \\
$\mathrm{Mn}^{2+}$ & 5 & & $\mathrm{Cu}^{2+}$ & 10 & \\
$\mathrm{~Pb}^{2+}$ & 10 & \\
$\mathrm{~Pb}^{2+}$ & 10 & 92 & & & \\
$\mathrm{Mn}^{2+}$ & 10 & & $\mathrm{~K}^{+}$ & 1000 & 95 \\
$\mathrm{Ni}^{2+}$ & 5 & 93 & $\mathrm{Na}^{+}$ & 1000 & \\
$\mathrm{Co}^{2+}$ & 5 & & $\mathrm{Mg}^{2+}$ & 1000 & \\
$\mathrm{Zn}^{2+}$ & 5 & & 1000 & \\
$\mathrm{Ca}^{2+}$ & & & \\
$\mathrm{Al}^{2+}$ & 25 & 91 & $\mathrm{NO}_{3}^{-}$ & 1000 & 95 \\
$\mathrm{Fe}^{2+}$ & 25 & & $\mathrm{CO}^{-2}$ & 1000 & \\
\hline
\end{tabular}

were studied at $40 \mu \mathrm{g} \mathrm{L}^{-1} \mathrm{Hg}$ concentration and keeping other parameters constant. The recovery values of $\mathrm{Hg}$ (II) affected by sample volume above 20 and $30 \mathrm{~mL}$ for

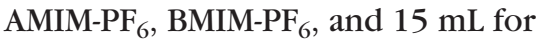
BeMIM-PF 6 resulted in decreases of extraction recoveries. Above these sample volumes, the recovery was affected decreasingly.

\section{Analysis of Samples}

In this study. the developed microextraction method for the enrichment of mercury was applied to real water samples with BMIM-PF 6 under optimum conditions. In the tap water and mineral water samples, mercury was not detected. For this, unspiked tap water and mineral water samples and their spiked samples at two concentration levels of $10 \mu \mathrm{g} \mathrm{L}^{-1}$ and $50 \mu \mathrm{g} \mathrm{L}^{-1}$ were analyzed by using the developed IL-mDLLME method $(n=3)$. The results are listed in Table IV. The relative recoveries at three concentration levels were in the range of 97.6-107.6\%, with RSDs within the range of $1.3-2.8 \%$, demonstrating that the proposed method can be used for the determination of trace $\mathrm{Hg}$ (II) in real environmental water samples. The performance of the developed method was evaluated with other DLLME methods for inorganic mercury. As shown in Table V, the developed method for preconcentration of mercury had

TABLE III Analytical Parameters

\begin{tabular}{lccc}
\hline Parameters & \multicolumn{3}{c}{ Ionic Liquids } \\
& AMIM-PF $_{6}$ & BMIM-PF $_{6}$ & BeMIM-PF $_{6}$ \\
\hline Linear range $\left(\mu \mathrm{g} \mathrm{L}^{-1}\right)$ & $2-100$ & $5-250$ & $2-200$ \\
$\mathrm{R}^{2}$ & 0.9942 & 0.9954 & 0.9938 \\
LOD $\left.^{2} \mu \mathrm{g} \mathrm{L}^{-1}\right)$ & 0.44 & 0.18 & 0.54 \\
Intra-day RSD (\%) & $1.52^{\mathrm{a}}$ & $3.37^{\mathrm{b}}$ & $6.73^{\mathrm{c}}$ \\
Inter-day RSD (\%) & $8.66^{\mathrm{a}}$ & $4.52^{\mathrm{b}}$ & $5.94^{\mathrm{c}}$ \\
EF & 31.6 & 38.3 & 46.1 \\
\hline
\end{tabular}

${ }^{\mathrm{a}}$ For $10 \mu \mathrm{g} \mathrm{L}^{-1}, \mathrm{n}=3$;

${ }^{\mathrm{b}}$ For $5 \mu \mathrm{g} \mathrm{L} \mathrm{L}^{-1}, \mathrm{n}=3$;

${ }^{c}$ For $2 \mu \mathrm{g} \mathrm{L}^{-1}, \mathrm{n}=3$. 
TABLE IV

Recovery Results of Sample Analysis ( $n=3$ )

\begin{tabular}{lccc}
\hline Sample & $\begin{array}{c}\text { Added } \\
\left(\mu \mathrm{g} \mathrm{L}^{-1}\right)\end{array}$ & $\begin{array}{c}\text { Found } \\
\left(\mu \mathrm{g} \mathrm{L}^{-1}\right)\end{array}$ & $\begin{array}{c}\mathrm{ER} \pm \mathrm{RSD} \\
(\%)\end{array}$ \\
\hline Tap water & - & $\mathrm{ND}^{*}$ & - \\
& 10 & $10.1 \pm 0.3$ & $101.4 \pm 2.8$ \\
& 50 & $53.8 \pm 3.4$ & $107.6 \pm 1.5$ \\
Mineral water & - & $\mathrm{ND}^{*}$ & - \\
& 10 & $9.8 \pm 0.5$ & $97.6 \pm 1.7$ \\
& 50 & $49.9 \pm 2.8$ & $99.8 \pm 1.3$ \\
\hline
\end{tabular}

*ND: Not detected.

small LOD values, high accuracy levels, and good linear range.

\section{CONCLUSION}

In the present work, a dispersive liquid liquid microextraction methodology based on the use of $\mathrm{Fe}_{3} \mathrm{O}_{4}$ magnetic nanoparticles supported with imidazolium ionic liquid was developed to enrich mercury in tap water and mineral water samples. The use of nanoparticles in this system offer a rapid extraction without any centrifugation steps. Further, this method combines the advantages of the DLLME technique with the use of ionic liquid as a green extractant in small amounts. The whole analytical procedure, including $\mathrm{pH}$, complexation, MNP amount, extraction time were optimized for all three ionic liquids. There was no significant difference observed when changing the cationic groups for ionic liquids. This method was successfully applied to the preconcentration of inorganic mercury in real natural waters achieving accuracy between $97.6-107.6 \%$ for $10 \mu \mathrm{g} \mathrm{L}{ }^{-1}$ and $50 \mu \mathrm{g} \mathrm{L}^{-1}$ standard additions.

\section{ACKNOWLEDGMENT}

This work was supported by The Scientific and Technological Research Council of Turkey (Project no: 214Z269).

$\overline{\text { Received February 2, } 2018 .}$

TABLE V

Comparison of Proposed Method With Other DLLME Methods for Hg(II)

\begin{tabular}{lccccc}
\hline Method & Sample & $\begin{array}{c}\text { Linear Range } \\
\left(\mu \mathrm{g} \mathrm{L}^{-1}\right)\end{array}$ & $\begin{array}{c}\text { LOD } \\
\left(\mu \mathrm{g} \mathrm{L}^{-1}\right)\end{array}$ & $\begin{array}{c}\text { Spiked Recov. } \\
(\%)\end{array}$ & Ref. \\
\hline $\begin{array}{l}\text { Traditional } \\
\text { DLLME }\end{array}$ & Water & $10.0-300.0$ & 2.8 & $93.6-104.0$ & $(32)$ \\
$\begin{array}{l}\text { Ion pair-based } \\
\text { surfactant-assisted } \\
\text { DLLME }\end{array}$ & Fish & $20-20000$ & 9 & $98.1-100.5$ & $(33)$ \\
IL-DLLME & Blood & $0.15-8.50$ & 0.03 & $96-103$ & $(34)$ \\
$\begin{array}{l}\text { DLLME } \\
\text { IL-mDLLME }\end{array}$ & $\begin{array}{l}\text { Water } \\
\text { Tap \& } \\
\text { mineral } \\
\text { water }\end{array}$ & $1-1000$ & 0.62 & $86.6-95.1$ & $(35)$ \\
& $5-250$ & 0.18 & $97.6-107.6$ & This \\
& & & & & work \\
\hline
\end{tabular}

\section{REFERENCES}

1. M. Rezaee, Y. Assadi, M.R.M. Hosseini, E. Aghaee, F. Ahmadi, and S. Berijani, J. Chromatogr. A 1116, 1 (2006)

2. C. Yao, T. Li, P. Twu, W.R. Pitner, and J.L. Anderson, J. Chromatogr. A 1218, 1556 (2011).

3. E.Z. Jahromi, A. Bidari, Y. Assadi, M.R.M. Hosseini, and M.R. Jamali, Anal. Chim. Acta 585, 305 (2007).

4. M. Baghdadi, and F. Shemirani, Anal. Chim. Acta 613, 56 (2008).

5. Y. Zhang, Y. Zhang, Q. Zhao, W. Chen, and B. Jiao, Food Anal. Method 9, 596 (2016).

6. Q. Zhou, and C. Ye, Microchim. Acta 162, 153 (2008).

7. R. Liu, J.F. Liu, Y.G. Yin, X.1. Hu, and G.B. Jiang, Anal. Bioanal. Chem. 393, 871 (2009).

8. T.D. Ho, C. Zhang, L.W. Hantao, and J.L. Anderson, Anal. Chem. 86, 262 (2014).

9. S. Li, S. Cai, W. Hu, H. Chen, and H. Liu, Spectrochim Acta B 64, 666 (2009)

10. H. Chen, P. Du, J. Chen, S. Hu, S. Li, and H. Liu, Talanta 81, 176 (2010).

11. E. Molaakbari, A. Mostafavi, and D. Afzali, J. Hazard. Mater. 185, 647 (2011).
12. H. Zhang, $X$. Chen, and $X$. Jiang, Anal. Chim. Acta 689, 137 (2011).

13. M. Tuzen, and Ö.Z. Pekiner, Food Chem. 188, 619 (2015).

14. J.S. Suleiman, B. Hu, H.Y. Peng, and C.Z. Huang, Talanta 77, 1579 (2009).

15. O. Bagheri, A.A. Zandi, Chromatographia 74, 483 (2011).

16. Y.R Song, S.L. Zhao, P. Tchounwou, and Y.M. Liu, J. Chromatogr. A 1166, 79 (2007).

17. G.Y Zhao, S.J. Song, C. Wang, Q.H. $\mathrm{Wu}$, and $\mathrm{Z}$. Wang, Anal. Chim. Acta 708, 155 (2011).

18. I.P. Roman, A. Chisvert, and A. Canals, J. Chromatogr. A 1218, 2467 (2011).

19. B.M.W. Fong, T.S. Siu, J.S.K. Lee, and S. Tam, J. Anal. Toxicol. 31, 281 (2007).

20. WHO, 2003. Elemental Mercury and Inorganic Mercury Compounds: Human Health Aspects. Concise International Chemical Assessment Document 50. World Health Organization, Geneva.

21. L. Adlnasab, H. Ebrahimzadeh, A.A. Asgharinezhad, M.N. Aghdam, A. Dehghani, and S. Esmaeilpour, Food Anal. Method 7, 616 (2014).

22. R. Rodríguez-Fernández, E. PeñaVázquez, and P. Bermejo-Barrera, 
At. Spectrosc. 37, 238 (2016).

23. A. Jamshed, T. G. Kazi, M. Tüzen, H. I.Afridi, and Naeemullah, At. Spectrosc. 37, 184 (2016).

24. Y. Zhang, M. Xu, C. Wei, S.Y. Zhang, H. Gao, and R. Liu, At. Spectrosc. 37, 190, (2016).

25. Z.L. Liu, Y.J. Liu, K.L. Yao, Z.H. Ding, J. Tao, and X. Wang, J. Mater. Synth. Process. 10, 83 (2002).

26. B. Kalska-Szostko, U. Wykowska, K. Piekut, and D. Satula, Colloid Surface A 450, 15 (2014).

27. S. Kumar, V. Singh, S. Aggarwal, U. K. Mandal, and R.K. Kottnala, J. Phys. Chem. C 114, 6272 (2010).

28. S.A. Jadhav, and S.V. Patil, Fronti. Mater. Sci. 8, 193 (2014).

29. A. Afkhami, and M. Bahram, Spec- trochim. Acta Part A: Mol. Biomol. Spectrosc. 61, 869 (2005).

30. C.E. Sabel., J.L. Shepherd, and S. Siemann, Anal. Biochem. 391, 74 (2009).

31. E. Kabalcilar, and F. Karipcin, Acta Chim. Slov. 54, 242 (2007).

32. A. Niazi S. Habibi, and M. Ramezani, Arab. J. Chem. 8, 706 (2015).

33. M. Sadeghi, Z. Nematifar, M. Irandoust, N. Fattahi, P. Hamzei, A. Barati, M. Ramezani, and M. Shamsipur, RSC Adv. 5, 100511 (2015).

34. H. Shirkhanloo, A. Khaligh, H. Z. Mousavi, M. M. Eskandari, and A. A. Miran-Beigi, Chem. Pap. 69, 779 (2015).

35. J. Li, W. Lu, J. Ma, L. Chen, Microchim. Acta 175, 301 (2011)

\section{* CRC Press/Taylor \& Francis announces the availability of}

\section{Measuring Elemental Impurities in Pharmaceuticals: A Practical Guide}

\section{Robert J. Thomas, CSci, CChem, FRSC Principal Consultant Scientific Solutions Gaithersburg, MD}

- The complete guide to measuring elemental impurities in pharmaceutical and nutraceutical materials.

- Covers heavy metals testing in the pharmaceutical industry from an historical perspective.

- Gives an overview of current USP Chapters <232> <233> and <2232> and ICH Q3D Step 4 Guidelines.

- Explains the purpose of validation protocols used in Chapter <233>, including how J-values are calculated

- Describes fundamental principles and practical capabilities of ICP-MS and ICP-OES.

- Offers guidelines about the optimum strategy for risk assessment.

- Provides tips on how best to prepare and present your data for regulatory inspection.

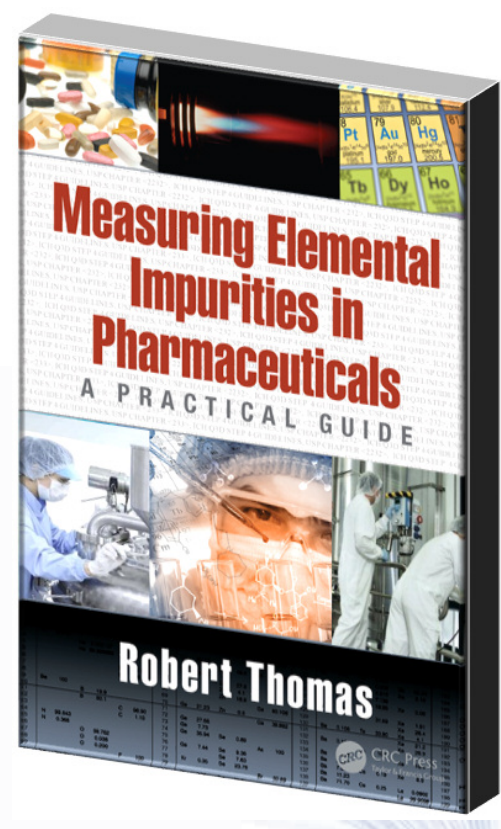

\section{Online www.crcpress.com}

